Climate and soil respiration

\section{How well can we predict soil respiration with climate indicators, now and in the future?}

C. T. Berridge ${ }^{1}$, L. H. Hadju ${ }^{2}$, and A. J. Dolman ${ }^{1}$

${ }^{1}$ VU University Amsterdam, Department of Earth Sciences, Boelelaan 1085, $1081 \mathrm{HV}$, Amsterdam, the Netherlands

${ }^{2}$ Department of Geography, University of Cambridge, UK

Received: 9 January 2014 - Accepted: 14 January 2014 - Published: 4 February 2014

Correspondence to: C. T. Berridge (c.t.berridge@vu.nl)

Published by Copernicus Publications on behalf of the European Geosciences Union.
C. T. Berridge et al.

Title Page

Abstract

Introduction

Conclusions

References

Tables

Figures

14

$\rightarrow 1$

4

Back

Close

Full Screen / Esc

Printer-friendly Version

Interactive Discussion 


\section{Abstract}

Soils contain the largest terrestrial store of carbon; three times greater than present atmospheric concentrations, whilst the annual soil-atmosphere exchange of carbon is an order of magnitude larger than all anthropogenic effluxes. Quantifying future pool 5 sizes and fluxes is therefore sensitive to small methodological errors, yet unfortunately remains the second largest area of uncertainty in Intergovernmental Panel on Climate Change projections.

The flux of carbon from heterotrophic decomposition of soil organic matter is parameterized as a rate constant. This parameter is calculated from observed total soil carbon efflux and contemporaneously observed temperature and soil moisture. This metric is then used to simulate future rates of heterotrophic respiration, as driven by the projections of future climate- temperature and precipitation. We examine two underlying assumptions: how well current climate (mean temperature and precipitation) can account for contemporary soil respiration, and whether an observational parameter derived from this data will be valid in the future.

We find mean climate values to be of some use in capturing total soil respiration to the $95 \%$ confidence interval, but note an inability to distinguish between subtropical and Mediterranean fluxes, or wetland-grassland and wetland-forest fluxes.

Regarding the future, we present a collection of $\mathrm{CO}_{2}$ enrichment studies demonstrating a strong agreement in soil respiration response (a $25 \%$ increase) independent of changes in temperature and moisture, however these data are spatially limited to the northern mid-latitudes.

In order to "future-proof" simple statistical parameters used to calculate the output from heterotrophic soil respiration, we propose a correction factor derived from empirical observations, but note the spatial and temporal limitations.

In conclusion, there seems to be no sound basis to assume that models with the best fit to contemporary data will produce the best estimates of future fluxes, given the methods, future dynamics and the nature of the observational constraints. Only
BGD

11, 1977-1999, 2014

Climate and soil respiration

C. T. Berridge et al.

Title Page

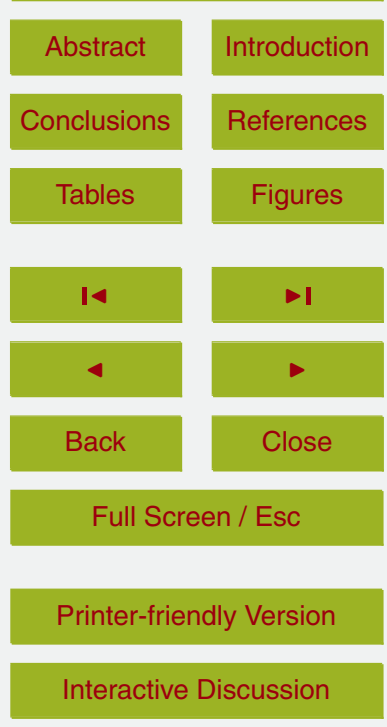


through long-term field observations and appropriate, perhaps novel, data collection can we improve statistical respiration modelling, without adding mechanistic details at a computational cost.

\section{Introduction}

5 The future response of the terrestrial carbon cycle is the second largest contributor to climate prediction uncertainty (Bodman et al., 2013). The terrestrial carbon balance is the product of net primary production (NPP) minus effluxes through heterotrophic respiration (Arneth et al., 2010), and complicated through natural (e.g. fire and herbivory) and anthropogenic (land use change and biogeochemical cycle alterations) dis10 turbance processes. Resolved globally, recent estimates suggest a terrestrial carbon sink of 2.2 $\pm 0.4 \mathrm{PgCyr}^{-1}$ (Le Quére et al., 2009), largely due to increases in productivity associated with recent aforestation, reforestation, abandonment of farmland and, to a lesser extent, $\mathrm{CO}_{2}$ and nitrogen enrichment (Pan et al., 2011). The first signs of sink saturation in European forests are postulated by Nabuurs et al. (2013), and future 15 dynamics are not only dependent on productivity efficacy, but also the sensitivity of soil respiration to changes in climate.

Microbial decomposition of soil organic carbon (SOC) and leaf litter is enzymemediated, and as such is a strongly temperature sensitive process (Lloyd and Taylor, 1994; Knorr et al., 2005). It is therefore anticipated that higher soil temperatures, in the presence of adequate water, will increase microbial activity and thus the heterotrophic respiration ( $\mathrm{Rh}$ ) component of the carbon cycle (Cox et al., 2000), leading to a large positive climate-carbon cycle feedback. Of particular concern then, are the large estimates of stored carbon in the world's soils, the decomposition of which is susceptible to increases in temperature: Jobbágy and Jackson (2000) estimated $2344 \mathrm{PgC}$ to $3 \mathrm{~m}$ depth; nearly four times the amount of $C$ in plant biomass and three times greater than atmospheric $\mathrm{CO}_{2}$. This implies that the flux of soil respiration to the atmosphere can continue unabated, even if above-ground inputs of new, labile carbon are reduced.
BGD

11, 1977-1999, 2014

Climate and soil

respiration

C. T. Berridge et al.

Title Page

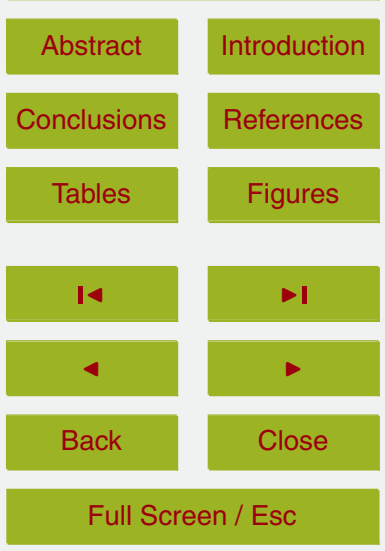

Printer-friendly Version

Interactive Discussion 
These stores are highly dynamic: the annual flux of respired carbon to the atmosphere is an order of magnitude higher than all annual anthropogenic emissions (Field and Raupach, 2004). Clearly, even small changes in this flux could have huge ramifications for the atmospheric $\mathrm{CO}_{2}$ pool and any associated feedbacks. Under future climate 5 scenarios, it is feared that soil respiration will exceed net primary production and the currently observable, globally averaged carbon sink will become a source.

The current modeling methodology, used in all coupled global climate models in the latest Intergovernmental Panel on Climate Change report (Todd-Brown et al., 2012; IPCC, 2013), is to derive heterotrophic soil carbon efflux values by up-scaling a first 10 order decay parameter observable at the site-scale over the worldwide, estimated, soil pools. The global applicability and conservancy of intrinsic rates of decomposition have been called into question (Davidson and Janssens, 2006). Chiefly, this method relies singularly on an interpolated rate constant, derived from temperature-efflux correlations at the site-scale, which is then extrapolated to spatial and, critically, temporal 15 ranges far outside the boundary conditions of its' formulation. Such a statistical parameter is not appropriate to forecast how a complex, process-based system will behave under conditions different to those occurring when the parameter is derived, i.e. conditions not observed when the regression between temperature and efflux is interpolated. Additionally, the temperature and moisture values used by the decay parameter are calculated in the future by predicted temperature and precipitation, another key source of uncertainty. Regardless, there is still much support from both theory and observations: for example, Litton et al. (2011) show a strong positive linear relationship between mean annual temperature and respiration in Hawaiian tropical montane wet forests.

25 We use meta-analysis to test the assumptions that climate indicators can estimate soil carbon efflux now and in the future, on a macro scale analogous to the coarse scale of climate models.
BGD

11, 1977-1999, 2014

Climate and soil respiration

C. T. Berridge et al.

Title Page

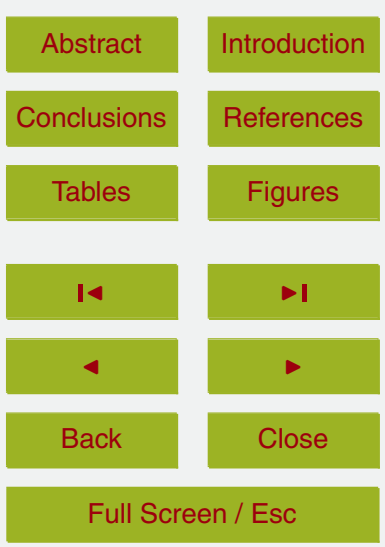

Printer-friendly Version

Interactive Discussion 


\section{Methods}

Using the publicly available dataset of Bond-Lamberty and Thomson (2010), all site data that contains soil respiration (Rs), mean annual precipitation (MAP) and mean annual temperature (MAP) is collated. Additionally, data pertaining to gross primary pro-

5 ductivity (GPP), net ecosystem productivity (NEP) and estimates of the heterotrophic to autotrophic ratio of soil respiration is also considered.

To avoid pseudoreplication, the data is examined on a per paper basis. If a paper reports respiration measurements taken at the same site over a number of years with the same MAT and MAP throughout, then the average total soil respiration (Rs) is used, as (Crawley, 2010). Likewise, papers providing Rs data that is not spatially independent are also averaged to arrive at one value for the reported MAP and MAT (the climate) and location.

With papers that sought to study the artificial manipulation of soil respiration as a proxy for climate change, i.e. through $\mathrm{CO}_{2}$ fertilization, temperature modifications or soil moisture manipulations, the control study values are used, unless otherwise stated. In studies that reported the same MAP and MAT values, but provided separate Rs values for different aboveground species cover or stand age, are also averaged and considered representative of a heterogeneous landscape within the respective prevailing climatic means. The only further manipulation of data is the removal/separation of especially high altitude sites (>2000 m) when a two-tailed $t$ test confirms the mean of these data as statistically different from the greater population.

\section{Results and discussion}

\subsection{Contemporary fluxes}

The distribution of all known field observations of total soil respiration (Rs) is plotted on 25 Fig. 1. Even at a glance, a distribution bias is obvious. Less than $11 \%$ are in high north-
Climate and soil respiration

C. T. Berridge et al.

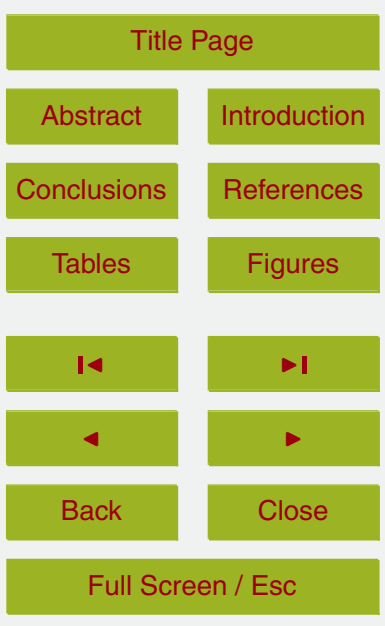

Printer-friendly Version

Interactive Discussion 
ern latitudes: in other words, roughly 27 independent sites to represent 14.7 million $\mathrm{km}^{2}$ of boreal forest, covering $11 \%$ of the Earth's land area (Bonan and Shugart, 1989), and tundra, a further $6 \%$ (Oechel and Vourlitis, 1994), totaling some 25 (Gorham, 1991) to $>50 \%$ (Hobbie et al., 2000; Tarnocai et al., 2009) of the global carbon pool. Addition5 ally, there appears to be a bias towards coastal sites, probably reflecting natural population trends (Fig. 1 inset). A recent field study by Berridge et al. (2013) shows a strong increase in summer soil respiration with distance inland. If this observation pertains to a consistent mechanism, then the current distribution of field sites may well be yielding misleading meta-trends. The size of the circles in Fig. 1 is a product of the observed 10 magnitude of total soil respiration. Globally, the assumption that warmer mean annual temperatures (MAT) and mean annual precipitation (MAP) produce higher respiration is confirmed as significant, but weakly $\left(r^{2}=0.19 p<0.001\right.$ and $r^{2}=0.11 p<0.001$, respectively).

Tukey's Honest Significance Difference Test (HSD) calculates the significance of pairwise differences in sample means. Figure 2 uses HSD to illustrate the mean differences between terrestrial biomes in total soil respiration (Rs), and the corresponding mean annual temperature (MAT) and precipitation (MAP) where the respiration data was observed. Whenever the horizontal bar does not cross zero, there is a significant difference in mean value; the ninety five per cent confidence interval is proportional to the 20 length of the bars. At a glance, the climate drivers accord with the values of total soil carbon efflux at the ecosystem and biome scale, suggesting that the differences in MAT and MAP that determine the biome classification are sufficient to also estimate soil respiration. However, no significant difference is observable between subtropicalMediterranean respiration and temperate-subtropical respiration, in the presence of tion for these biomes. Likewise, there is a statistically significant difference between wetland-grassland and wetland-forest respiration, in the absence of a commensurate difference in MAP and MAT (Supplement 1). This reveals that processes and conditions within a climate zone, such as porosity, soil organic matter and phenology (Raich and

BGD

11, 1977-1999, 2014

Climate and soil respiration

C. T. Berridge et al.

Title Page
Abstract

Conclusions

Tables

14

4

Back

\section{Full Screen / Esc}

Printer-friendly Version

Interactive Discussion
- I
Close 
Tufekcioglu, 2000), are strong enough to exert a control on total soil respiration greater than can be inferred from climatic averages alone. Importantly, fallacious climate-based soil carbon flux estimates, particularly in carbon-rich arctic wetlands, will accumulate into erroneous predictions of the terrestrial carbon cycle feedback. This is perhaps 5 prevalent in the mid-latitudes $\left(30-60^{\circ} \mathrm{N}\right.$ and S: Fig. 1; inset), where mean annual temperature (MAT) and mean annual precipitation (MAP) are poor explanatory variables of total soil respiration $\left(r^{2}=0.07 p<0.001, r^{2}=0.014 p=0.05\right.$; MAP and MAT, respectively). The site-specific variation is such that simple temperature-moisture parameterizations in these regions are unlikely to capture reality, and subsequently carry forward 10 significant uncertainty in bottom-up estimates of regional and global soil respiration rates.

Taking this further, Fig. 3 shows mid-latitude soil respiration in relation to the two primary climatic drivers: temperature and precipitation. The data is discretized into ranges, where each increment in mean annual precipitation (MAP) shows a commen15 surate increase in the median respiration value and upper quartiles (Fig. 3a), up until the highest MAP range. This points to a general increase in respiration facilitated by increased precipitation. The dip at the uppermost extreme $(2000-3000 \mathrm{~mm})$ is likely due to the drawbacks of using MAP as a proxy for bio-available water: with high precipitation, run-off becomes a more important component of the hydrological balance, allowing water to bypass infiltration, thence levels of evapotranspiration tend to remain relatively constant in sites experiencing $>1500 \mathrm{~mm}$ of MAP (Schulze, 2005). Additionally, several sample sites within the highest precipitation box-plot (Fig. 3a) are at high-altitude where, despite receiving large amounts of water, infiltration into the soil is inhibited by seasonally frozen grounds and snow cover (Indeed, an $F$ test shows the mean of the high altitude sites to be statistically independent).

Conversely, the box-plots of respiration within incremental mean annual temperature (MAT) ranges proffer little obvious average trend (Fig. 3c), a finding that runs counter to the well-documented site-scale dependency of respiration on temperature (Kirschbaum, 1995; Fang and Moncrieff, 2001; Karhu et al., 2010). One consistent
BGD

11, 1977-1999, 2014

Climate and soil

respiration

C. T. Berridge et al.

Title Page

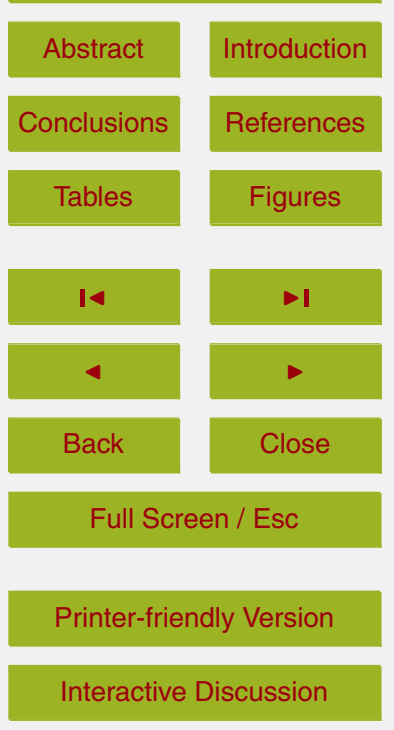

Interactive Discussion 
pattern in Fig. $2 \mathrm{c}$ is the increase in the upper range of respiration in concert with increasing temperature, coinciding with a relatively stable lower range (the "whiskers" of the box-plots). One interpretation is, in line with Arrhenius kinetics of decomposition and experimental observations (Davidson et al., 1998; Tuomi et al., 2008; Zanchi et al., 5 2012), that increases in temperature stimulate metabolic activity of soil microbes and thus increase the maximum respired carbon. Remembering Liebig's law of the Minimum (Von Liebig, 1840), this can only be realized when there are no other limitations. In this case, increased respiration with higher mean annual temperature is only realized when there is a transport medium of sufficient quality to bring nutrients of sufficient 10 abundance (Fleischer et al., 2013) and extract waste from metabolically active sites, i.e. bio-available soil moisture. In the absence of limiting nutrients, substrates and their locomotion, respiration will be constrained regardless of any temperature increases, hence the constant lowest extremes in the ranges of respiration observed across the box-plots of Fig. 3c.

15 Interestingly, if one correlates the corresponding MAP with the respiration values used in each temperature range as presented in Fig. 3c, statistically significant associations can be found (Fig. $3 \mathrm{~d}$; data taken from $9-12^{\circ} \mathrm{C}$ range within Fig. $2 \mathrm{c} ; r=0.74$, $p<0.001)$. This has the coarse effect of controlling for the influence of temperature on respiration in order to better assess the control that precipitation alone exerts. When this process is repeated for temperature, by plotting the respiration data within the discrete MAP brackets with their corresponding MAT as the independent variable, no significant correlations are found (Fig. $3 b$ ). This is despite the data presented within Fig. 3 arriving from papers frequently reporting far stronger relationships between temperature and respiration than with moisture at the site-scale. Evidently, this correlation 25 thus rather brakes down during inter-site comparisons.

To address the problems in using MAP as a proxy for bio-available soil moisture, we utilized MODIS satellite estimates of annual precipitation and potential evapotranspiration for the relevant years and locations of study sites. MODIS potential evapotranspiration (PET) correlated very well with MAT $\left(r^{2}=0.8\right)$, suggesting the proxies are
BGD

11, 1977-1999, 2014

Climate and soil

respiration

C. T. Berridge et al.

Title Page

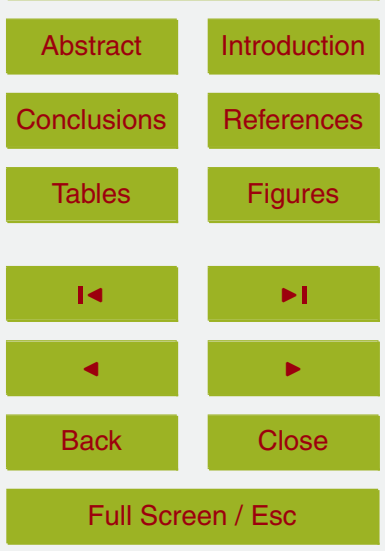

Printer-friendly Version

Interactive Discussion 
comparable. A principal component analysis (PCA) resolving for the following variables: soil respiration, mean annual temperature, mean annual precipitation, MODIS precipitation estimate for measurement year, MODIS estimate of potential evapotranspiration and latitude, unambiguously places mean and MODIS precipitation in the same plane 5 as total soil respiration (Supplement 2). Potential evapotranspiration is tightly aligned with temperature, as expected, but not with Rs. This supports the above supposition that moisture emerges as the key cross-site constraint of soil respiration in the midlatitudes, with little association to temperature, on annual timescales.

As discussed above, emissions from the decomposition of terrestrial carbon by heterotrophic respiration are often calculated as the product of a temperature sensitive decay rate acted upon the carbon pool. In other words, temperature and moisture can only facilitate decomposition if there is something to decompose, and total soil respiration is also sensitive to ambient soil carbon content. Surprisingly then, there is no obvious association between soil texture and soil respiration at this scale (Supplement 3 ), as might be expected given the strong association between soil texture and chemical and physical protection of soil organic matter to decay (Baldock and Skjemstad, 2000).

\subsection{Soil Respiration in the Future}

A fundamental limitation in the statistical parameterization of heterotrophic respiration 20 is the lack of dynamism. Optimum biological functioning is a constant, but the realization of the optimum, as discussed above, is dynamic and will respond to numerous changes. One way to help "future-proof" the oft-used decay constant (typically from Lloyd and Taylor, 1994) is to incorporate a correction factor that accommodates anticipated change. Figure 5 shows the effect of artificially increased atmospheric carbon an increase $(n=20)$. This response is likely due to root-microbial interactions (Phillips, 2007), whereby $\mathrm{CO}_{2}$ enrichment allows more photosynthesis, so long as soil biota can cycle nutrients faster within the soil. In symbiotic plants, this demand is met by a com-
BGD

11, 1977-1999, 2014

Climate and soil respiration

C. T. Berridge et al.

Title Page

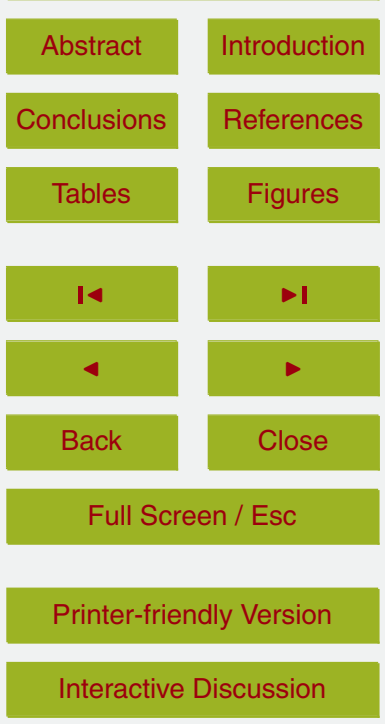


mensurate stimulation of arbuscular mycorrhizal fungi root colonization and rhizobacterial communities (Büscher et al., 2012), and observed as an increase in soil respiration following increased carbon allocation to root symbionts (Fig. 4). Non-symbiotic plants on the other hand benefit from a general promotion of plant growth promoting bacterial 5 species, such as Pseudomonas sp. (Marilley et al., 1999). However, the exact explanation may be very site-specific, and in some instances can be due to a single bacterium (Pseudomonas mendocina promotes lettuce growth under elevated $\mathrm{CO}_{2}$; Kohler et al., 2009). Additionally, the response of bacterial and fungal groups are disparate and dependent on both soil nutrient status and plant type; both of which are also dynamic 10 (Drigo et al., 2009). The length of the $\mathrm{CO}_{2}$ enrichment studies should also be noted as, in the long-term following successional changes, plant-soil interactions can reduce the digestibility of, for example, shortgrass steppe vegetation (Morgan et al., 2004), feeding back into reduced litter respiration (Fig. 4)

Despite these myriad complications, the response is fairly constant and has a small standard error $(24.71 \pm 1.94 \%)$. As none of the vegetation modules of the global circulation models used in the most recent IPCC report (Todd-Brown et al., 2012) have any mechanisms representing belowground biota or their symbiosis with above-ground communities, such a coarse correction factor is within the prevailing error. This does not improve the fundamental method, but is an appealing low-hanging fruit. We note

a caveat (Supplement 4): the stated average carbon efflux increase of $\sim 25 \%$ is not static, but depends on the initial efflux. The increase is higher when the initial flux is higher, but not in relative terms (a log-decrease with higher initial soil respiration of $\left.r^{2}=0.2\right)$.

\subsection{Limitations of the data}

MAT and MAP as proxies for soil temperature and bio-available soil moisture are not the actual, exact conditions experienced at the site when respiration is being measured, and they will seldom be realized in any given year. This was also a necessary source of error, however, as data containing study temperature and precipitation is too meager to

BGD

11, 1977-1999, 2014

Climate and soil

respiration

C. T. Berridge et al.

Title Page

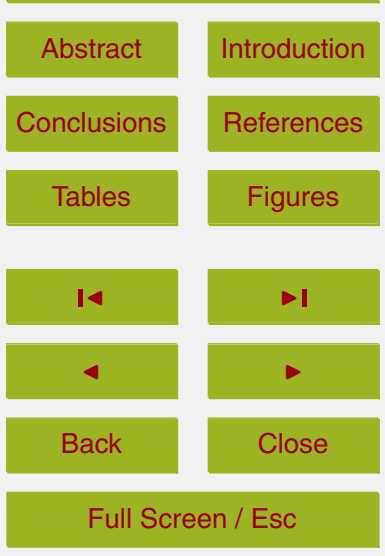

Printer-friendly Version

Interactive Discussion 
be statistically meaningful in meta-analysis. We would be quick to point out that, despite these flaws in using MAP as a surrogate for bio-available water, as well as being blind to other co-variables (such as hysteresis within the system, herbivore grazing, microbial community structure and aboveground floral type and abundance; Fig. 4) there are still 5 strong associations evident between annual soil respiration and MAP, in the absence of comparable correlation with MAT for mid-latitudes (Fig. 3).

However, as previously mentioned, Litton et al. (2011) were able to show a strong association between MAT and annual soil respiration in Hawaiian tropical montane forests. The location of their study could be telling; the tropics are not moisture limited, 10 so increases in productivity and respiration with temperature are likely, and first-order temperature-dependent statistical modeling of soil respiration may be quite relevant. Throughout the mid-latitudes, however, it seems that the same temperature dynamics run secondarily to other forcings (Fig. 3). A promising emerging solution is to include a microbial biomass step in the temperature-respiration equation that can respond to 15 site-specific secondary drivers (Wieder et al., 2013).

Perhaps more importantly, human influence may be such that the climate conditions alone may be incapable of predicting reality, and intensity and history of human settlement will have overriding controls on ecosystems (Ellis et al., 2010 and Fig. 4).

Perhaps most importantly, the soil respiration data used herein is annual values, and 20 is better described as "total soil carbon efflux", as the exact process that bore the carbon (autotrophic, heterotrophic or inorganic) is unknown in most studies. The relative contribution of heterotrophic vs. autotrophic is not constant spatially or temporally, so using in situ total carbon efflux to parameterize the heterotrophic component carries errors pertaining to the unknown origin and age of carbon (and therefore decomposition temperature), which is in practice parameterizing predictions of the unknown with the immeasurable (Subke and Bahn, 2010).
BGD

11, 1977-1999, 2014

Climate and soil respiration

C. T. Berridge et al.

Title Page

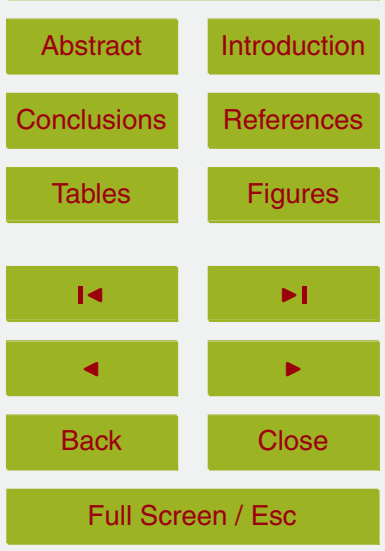

Printer-friendly Version

Interactive Discussion 


\section{Conclusions}

Resolving the heterotrophic respiration component of the carbon balance as a static function based on temperature and moisture is unchanged in the history of IPCC reporting (Todd-Brown et al., 2012). This can generally capture the broad patterns at 5 the biome level, within the spatially limited data, but there is little justification to use this to predict future fluxes. There have been advancements in our ability to separate respective sources of soil carbon effluxes (Vargas et al., 2012), observations of multifactor effects (Larsen et al., 2011; Dieleman et al., 2012), and some sound reasoning (Davidson et al., 2006; Subke and Bahn, 2010) that suggest this appealingly simplistic approach may be found lacking. Our observations and interpretations are in accordance with such views, however we do offer a correction factor for the effects of $\mathrm{CO}_{2}$ fertilization on soil carbon efflux, but note caution.

\section{Supplementary material related to this article is available online at http://www.biogeosciences-discuss.net/11/1977/2014/ 15 bgd-11-1977-2014-supplement.pdf.}

Acknowledgements. The research leading to these results has received funding from the European Community's Seventh Framework Programme (FP7 2007-2013) under grant agreement no. [238366]. We are also grateful to Ulrich Weber and Altug Ekici for providing accompanying data.

\section{References}

Andrews, J. A. and Schlesinger, W. H.: Soil $\mathrm{CO}_{2}$ dynamics, acidification, and chemical weathering in a temperate forest with experimental $\mathrm{CO}_{2}$ enrichment, Global Biogeochem. Cy., 15, 149-162, 2001.

Arneth, A., Harrison, S. P., Zaehle, S., Tsigaridis, K. Menon, S., Bartlein, P. J., Feichter, J., 25 Korhola, A., Kulmala, M., O'Donnell, D., Schurgers, G., Sorvari, S., and Vesala, T.: Terrestrial biogeochemical feedbacks in the climate system, Nat. Geosci., 3, 525-532, 2010.
BGD

$11,1977-1999,2014$

Climate and soil

respiration

C. T. Berridge et al.

Title Page

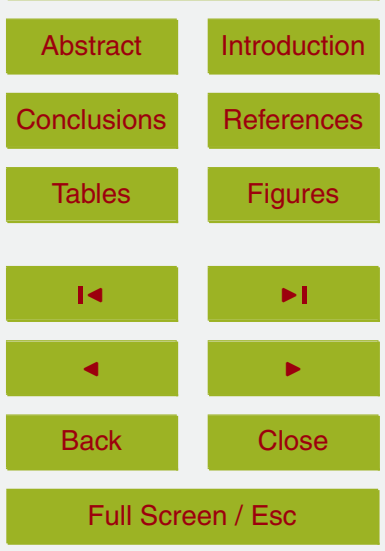

Printer-friendly Version

Interactive Discussion 
Bernhardt, E. S., Barber, J. J., Pippen, J. S., Taneva, L., Andrews, J. A., and Schlesinger, W. H.: Long-term effects of Free Air $\mathrm{CO}_{2}$ Enrichment (FACE) on Soil Respiration, Biogeochemistry, 77, 91-116, 2006.

Bodman, R. W., Rayner, P. J., and Karoly, D. J.: Uncertainty in temperature prejections reduced using carbon cycle and climate observations, Nat. Clim. Change, 3, 725-729, 2013.

Baldock, J. A. and Skjemstad, J. O.: Role of the soil matrix and minerals in protecting natural organic materials against biological attack, Org. Geochem., 31, 697-710, 2000.

Berridge, C. T., Fleischer, K., Bistinas, I., Stuttard, T. S., Ekici, A., Feldmeijer, W., Metcalfe, B., Dolman, A. J.: NitrogenOinduced reduction in soil respiration of European forests, Ecol. Appl., 10 in preparation, 2014.

Billings, S. A., Schaeffer, S. M., and Evans, R. D.: Soil microbial activity and N availability with elevated $\mathrm{CO}_{2}$ in Mojave Desert soils, Global Biogeochem. Cy., 18, GB1011, 2004.

Bond-Lamberty, B. and Thomson, A.: A global database of soil respiration data, Biogeosciences, 7, 1915-1926, doi:10.5194/bg-7-1915-2010, 2010.

15 Bonan, G. B. and Shugart, H. H.: Environmental factors and ecological processes in boreal forests, Annu. Rev. Ecol. Syst., 20, 1-28, 1989.

Büscher, M., Zavalloni, C., de Boulois, H. D., Vicca, S., Van den Berge, J., Declerck, S., Ceulemans, R., Janssens, I. A., and Nijs, I.: Effects of arbuscular mycorrhizal fungi on grassland productivity are altered by future climate and below-ground resource availability, Environ.

$20 \quad$ Exp. Bot., 81, 62-71, 2012.

Chen, X., Liu, J., Deng, Q., Yan, J., and Zhang, D.: Effects of elevated $\mathrm{CO}_{2}$ and nitrogen addition on soil organic carbon fractions in a subtropical forest, Plant Soil, 357, 25-34, 2012.

Cox, P. M., Betts, R. A., Jones, C. D., Spall, S. A., and Totterdell, I. J.: Acceleration of global warming due to carbon cycle feedbacks in a coupled climate model, Nature, 408, 184-187, 252000.

Craine, J. M., Wedin, D. A., and Reich, P. B.: Grassland species effects on soil $\mathrm{CO}_{2}$ flux track the effects of elevated $\mathrm{CO}_{2}$ and nitrogen, New Phytol., 150, 425-434, $2001 \mathrm{a}$.

Craine, J. M., Wedin, D. A., and Reich, P. B.: The response of soil $\mathrm{CO}_{2}$ flux to changes in atmospheric $\mathrm{CO}_{2}$, nitrogen supply and plant diversity, Glob. Change Biol., 7, 947-953, 2001b.

30 Crawley, M. J.: Statistics an Introduction Using R, John Wiley and Sons Ltd, ISBA 13: 978-0470-02298-6, 2010.

Daley, E., Palmroth, S., Stoy, P., Siqueira, M., Oishi, A. C., Juang, J., Oren, R., Porporato, A., and Katul, G. G.: The effects of elevated atmospheric $\mathrm{CO}_{2}$ and nitrogen amendments on 
subsurface $\mathrm{CO}_{2}$ production and concentration dynamics in a maturing pine forest, Biogeochemistry, 94, 271-287, 2009.

Davidson, E. A., Belk, E., and Boone, R. D.: Soil water content and temperature as independent or confounded factors controlling soil respiration in a temperate mixed hardwood forest, Glob.

$5 \quad$ Change Biol., 4, 217-227, 1998.

Davidson, E. A. and Janssens, I. A.: Temperature sensitivity of soil carbon decomposition and feedbacks to climate change, Nature, 440, 165-173, 2006.

Deng, Q., Zhou, G., Liu, J., Liu, S., Duan, H., and Zhang, D.: Responses of soil respiration to elevated carbon dioxide and nitrogen addition in young subtropical forest ecosystems in

10 China, Biogeosciences, 7, 315-328, doi:10.5194/bg-7-315-2010, 2010.

Dieleman, W. I. J., Vicca, S., Dijkstra, F. A., Hagedorn, F., Hovenden, M. J., Larsen, K. S., Morgan, J. A., Volder, A., Beier, C., Dukes, J. S., King, J., Leuzinger, S., Linder, S., Luo, Y., Oren, R., De Angelis, P., Tingey, D., Hoosbeek, M. R., and Janssens, I. A.: Simple additive effects are rare: a quantitative review of plant biomass and soil process responses to combined manipulations of $\mathrm{CO}_{2}$ and temperature, Glob. Change Biol., 18, 2681-2693, 2012.

Drigo, B., van Veen, J. A., and Kowalchuk, G. A.: Specific rhizosphere bacterial and fungal groups respond differently to elevated atmospheric $\mathrm{CO}_{2}$, ISME, 3, 1204-1217, 2009.

Edwards, N. T. and Norby, R. J.: Below-ground respiratory responses of sugar maple and red maple saplings to atmospheric $\mathrm{CO}_{2}$ enrichment and elevated air temperature, Plant Soil, 206, 85-97, 1999.

Egli, P., Maurer, S., Spinnler, D., Landolt, W., Günthardt-Goerg, M. S., and Körner, C.: Downward adjustment of carbon fluxes at the biochemical, leaf, and ecosystem scale in beechspruce model communities exposed to long-term atmospheric $\mathrm{CO}_{2}$ enrichment, Oikos, 92, 279-290, 2001.

Ellis, E. C., Goldewijk, K. K., Siebert, S., Lightman, D., and Ramankutty, N.: Anthropogenic transformation of the biomes, 1700 to 2000, Global Ecol. Biogeogr., 19, 589-606, 2010.

Fang, C. and Moncrieff, J. B.: The dependence of soil $\mathrm{CO}_{2}$ on temperature, Soil Biol. Biochem., 33, 155-165, 2001.

Field, C. B. and Raupach, M. R. (Eds.): The Global Carbon Cycle: Integrating Humans, Climate, and the Natural World, Scope 62, Island Press, Colorplate 1, 2004.

Gorham, E.: Northern peatlands: role in the carbon cycle and probable responses to climatic warming, Ecol. Appl., 1, 182-195, 1991.
BGD

11, 1977-1999, 2014

Climate and soil

respiration

C. T. Berridge et al.

Title Page

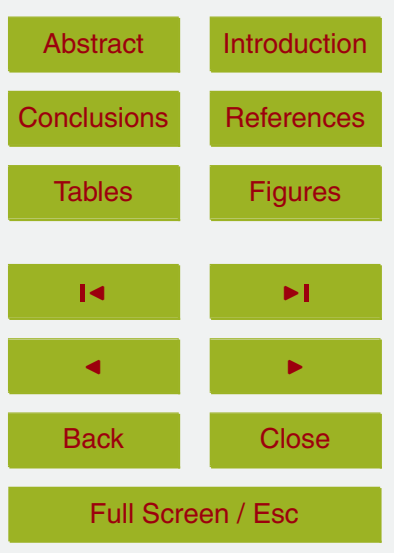

Printer-friendly Version

Interactive Discussion 
Fleischer, K., Rebel, K. T., van der Molen, M. K., Erisman, J. W., Wassen, M. J., van Loon, E. E., Montagnani, L., Gough, C. M., Herbst, M., Janssens, I. A., Gianelle, D., and Dolman, A. J.: The contribution of nitrogen deposition to the photosynthetic capacity of forests, Global Biogeochem. Cy., 27, 1-13, 2013.

5 Hobbie, S. E., Schimel, J. P., Trumbore, S. E., and Randerson, J. R.: Controls over carbon storage and turnover in high-latitude soils, Glob. Change Biol., 6, 196-210, 2000.

IPCC: Climate Change 2013: The Physical Science Basis, Cambridge University Press, http: //www.climatechange2013.org/images/uploads/WGIAR5WGI-12Doc2bFinalDraftAll.pdf, 2013.

10 Jobbágy, E. G. and Jackson, R. B.: The vertical distribution of soil organic carbon and its relation to climate and vegetation, Ecol. Appl., 10, 423-436, 2000.

Johnson, D., Geisinger, D., Walker, R., Newman, J., Vose, J., Elliot, K., and Ball, T.: Soil $\mathrm{pCO}_{2}$, soil respiration, and root activity in $\mathrm{CO}_{2}$-fumigated and nitrogen-fertilized ponderosa pine, Plant Soil, 165, 129-138, 1994.

Karhu, K., Fritze, H., Hämäläinen, K., Vanhala, P., Junger, H., Oinonen, M., Sonninen, E., Tuomi, M., Spetz, P., Kitunen, V., and Liski, J.: Temperature sensitivity of soil carbon fractions in boreal forest soil, Ecology, 91, 370-376, 2010.

King, J., Pregitzer, K., Zak, D., Sober, J., Isebrands, J., Dickson, R., Hendrey, G., and Karnosky, D.: Fine-root biomass and fluxes of soil carbon in young stands of paper birch and trembling aspen as affected by elevated atmospheric $\mathrm{CO}_{2}$ and tropospheric $\mathrm{O}_{3}$, Oecologia, 128, 237-250, 2001.

King, J. S., Hanson, P. J., Bernhardt, E., DeAngelis, P., Norby, R. J., and Pregitzer, K. S.: A multiyear synthesis of soil respiration responses to elevated atmospheric $\mathrm{CO}_{2}$ from four forest FACE experiments, Glob. Change Biol., 10, 1027-1042, 2004.

Kirschbaum, M. U. F.: The temperature dependence of soil organic matter decomposition, and the effect of global warming on soil organic C storage, Soil Biol. Biochem., 27, 753-760, 1995.

Kohler, J., Caravaca, F., del Mar Alguacil, M., and Roldán, A.: Elevated $\mathrm{CO}_{2}$ increases the effect of an arbuscular mycorrhizal fungus and a plant-growth-promoting rhizobacterium on structural stability of a semiarid agricultural soil under drought conditions, Soil Biol. Biochem., 41, 1710-1716, 2009.

Knorr, W., Prentice, I. C., House, J. I., and Holland, E. A.: Long-term sensitivity of soil carbon turnover to warming, Nature, 433, 298-301, 2005.

Climate and soil respiration

C. T. Berridge et al.

Title Page

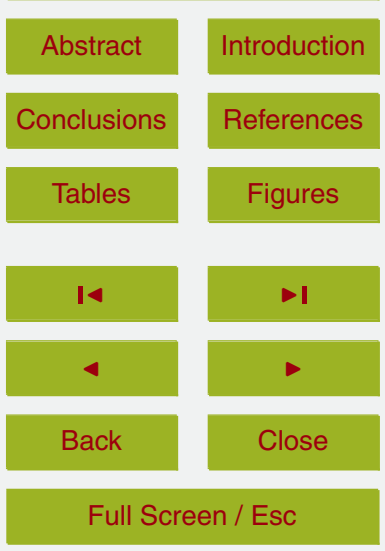

Printer-friendly Version

Interactive Discussion 
Larsen, K. S., Anderson, L. C., Beier, C., Jonasson, S., Albert, K. R., Ambus, P., Arndal, M. F., Carter, M. S., Christensen, S., Holmstrup, M., Ibrom, A., Kongstad, J., Van Der Linden, L., Maraldo, K., Michelsen, A., Mikkelsen, T. N., Pilegaard, K., Priemé, A., Ro-Poulsen, H., Schmidt, I. K., Selsted, M. B., and Stevnbak, K.: Reduced N cycling in response to elevated

5 $\mathrm{CO}_{2}$, warming, and drought in a Danish heathland: synthesizing results of the CLIMAITE project after two years of treatments, Glob. Change Biol., 17, 1884-1899, 2011.

Litton, C. M., Giardina, C. P., Albano, J. K., Long, M. S., and Asner, G. P.: The magnitude and variability of soil-surface $\mathrm{CO}_{2}$ efflux increase with mean annual temperature in Hawaiian montane wet forests, Soil Biol. Biochem., 43, 2315-2323, 2011.

10 Lloyd, J. and Taylor, J. A.: On the temperature dependence of soil respiration, Funct. Ecol., 8, 315-323, 1994.

Luo, Y., Jackson, R. B., Field, C. B., and Mooney, H. A.: Elevated $\mathrm{CO}_{2}$ increases belowground respiration in California grasslands, Oecologia, 108, 130-137, 1996.

Morgan, J. A., Mosier, A. R., Milchunas, D. G., LeCain, D. R., Nelson, J. A., and Parton, W. $\mathrm{J} .: \mathrm{CO}_{2}$ Enhances productivity, alters species composition, and reduces digestibility of shortgrass steppe vegetation, Ecol. Appl., 14, 208-219, 2004.

Marilley, L., Hartwig, U. A., and Aragno, M.: Influence of an elevated atmospheric $\mathrm{CO}_{2}$ content on soil and rhizosphere bacterial communities beneath Lolium perenne and Trifolium repens under field conditions, Microb. Ecol., 38, 39-49, 1999.

20 Nabuurs, G.-J., Lindner, M., Verkerk, P. J., Gunia, K., Deda, P., Michalak, R., and Grassi, G.: First signs of carbon sink saturation in European forest biomass, Nat. Clim. Change, 3, 792796, 2013.

Oechel, W. C., Vourlitis, G. L., Hastings, S. J., Zulueta, R. C., Hinzman, L., and Kane, D.: Acclimation of ecosystem $\mathrm{CO}_{2}$ exchange in the Alaskan Arctic in response to decadal climate warming, Nature, 406, 978-981, 2000.

Pan, Y., Birdsey, R. A., Fang, J., Houghton, R., Kauppi, P. E., Kurz, W. A., Phillips, O. L., Shvidenko, A., Lewis, S. L., Canadell, J. G., Ciais, P., Jackson, R. B., Pacala, S. W., McGuire, A. D., Piao, S., Rautiainen, A., Sitch, S., and Hayes, D.: A large and persistent carbon sink in the world's forests, Science, 333, 988-993, 2010.

30 Pendall, E., Del Grosso, S., King, J. Y., LeCain, D. R., Milchunas, D. G., Morgan, J. A., Mosier, A. R., Ojima, D. S., Parton, W. A., Tans, P. P., and White, J. W. C.: Elevated atmospheric $\mathrm{CO}_{2}$ effects and soil water feedbacks on soil respiration components in a Colorado grassland, Global Biogeochem. Cy., 17, 1046, 2003.

BGD

$11,1977-1999,2014$

Climate and soil

respiration

C. T. Berridge et al.

Title Page

Abstract

Conclusions

Tables

14

4

Back

Full Screen / Esc

Printer-friendly Version

Interactive Discussion 
Phillips, R. P.: Towards a rhizo-centric view of plant-microbial feedbacks under elevated atmospheric $\mathrm{CO}_{2}$, New Phytol. 173, 664-667, 2007.

Le Quéré, C., Raupach, M. R., Canadell, J. G., Marland, G., Bopp, L., Ciais, P., Conway, T. J., Doney, S. C., Feely, R. A., Foster, P., Friedlingstein, P., Gurney, K., Houghton, R. A., 5 House, J. I., Huntingford, C., Levy, P. E., Lomas, M. R., Majkut, J., Metzl, N., Ometto, J. P., Peters, G. P., Prentice, I. C., Randerson, J. T., Running, S. W., Sarmiento, J. L., Schuster, U., Sitch, S., Takahashi, T., Viovy, N., van der Werf, G. R., and Woodward, F. I.: Trends in the sources and sinks of carbon dioxide, Nat. Geosci., 2, 831-836, 2009.

Raich, J. W. and Tufekcioglu, A.: Vegetation and soil respiration: correlations and controls, Biogeochemistry, 48, 71-90, 2000.

Schulze, E. D.: Autecology: Whole Plant Ecology in Plant Ecology, Springer-Verlag, Berlin, 253-379, 2005.

Subke, J. and Bahn, M.: On the "temperature sensitivity" of soil respiration: can we use the immeasurable to predict the unknown?, Soil biol. Biochem., 42, 1653-1656, 2010.

Smart, D. R. and Peñuelas, J.: Short-term $\mathrm{CO}_{2}$ emissions from planted soil subject to elevated $\mathrm{CO}_{2}$ and simulated precipitation, Appl. Soil Ecol., 28, 247-257, 2005.

Tarnocai, C., Canadell, J. G., Schuur, E. A., Kuhry, P., Mazhitova, G., and Zimov, S.: Soil organic carbon pools in the northern circumpolar permafrost region, Global Biogeochem. Cy., 23, 111, 2009.

20 Todd-Brown, K. E. O., Hopkins, F. M., Kivlin, S. N., Talbot, J. M., and Allison, S. D.: A framework for representing microbial decomposition in coupled climate models, Biogeochemistry, online, 1-15, 2012.

Tuomi, M., Vanhala, P., Karhu, K., Fritze, H., and Liski, J.: Heterotrophic soil respirationComparison of different models describing its temperature dependence, Ecol. Model., 211, 182-190, 2008.

Vargas, R., Carbone, M. S., Reichstein, M., and Baldocchi, D. D.: Frontiers and challenges in soil respiration research: from measurements to model-data integration, Biogeochemistry, 102, 1-13, 2011.

Von Liebig, J.: Die Organische Chemie in Ihrer Anwendung auf Agrikultur und Physiologie, Friedrich Vieweg, 1840.

Wang, X., Nakatsubo, T., and Nakane, K.: Impacts of elevated $\mathrm{CO}_{2}$ and temperature on soil respiration in warm temperate evergreen Quercus glauca stands: an open-top chamber experiment, Ecol. Res., 27, 596-602, 2012.
BGD

11, 1977-1999, 2014

Climate and soil

respiration

C. T. Berridge et al.

Title Page

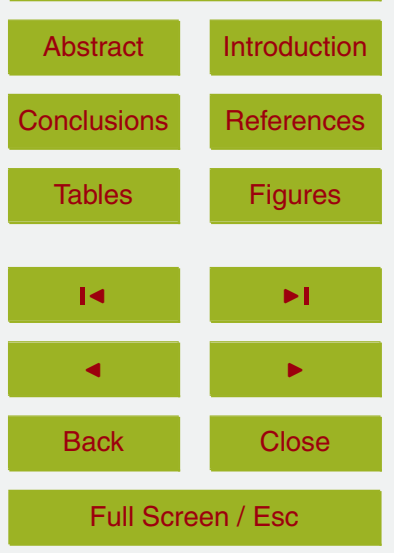

Printer-friendly Version

Interactive Discussion 
Wieder, W. R., Bonan, G. B., and Allison, S. D.: Global soil carbon projections are improved by modelling microbial processes, Nat. Clim. Change, 3, 909-912, 2013.

Zanchi, F. B., Waterloo, M. J., Kruijt, B., Kesselmeier, J., Luizão, F. J., Manzi, A. O., and Dolman, A. J.: Soil $\mathrm{CO}_{2}$ efflux in central Amazonia: environmental and methodological effects, $5 \quad$ Acta Amazonica, 42, 173-184, 2012.

Climate and soil respiration

C. T. Berridge et al.

Title Page

Abstract

Conclusions

Tables

14

4

Back

Full Screen / Esc

Printer-friendly Version

Interactive Discussion 
Distribution of all soil respiration field measurements, 1961-2010

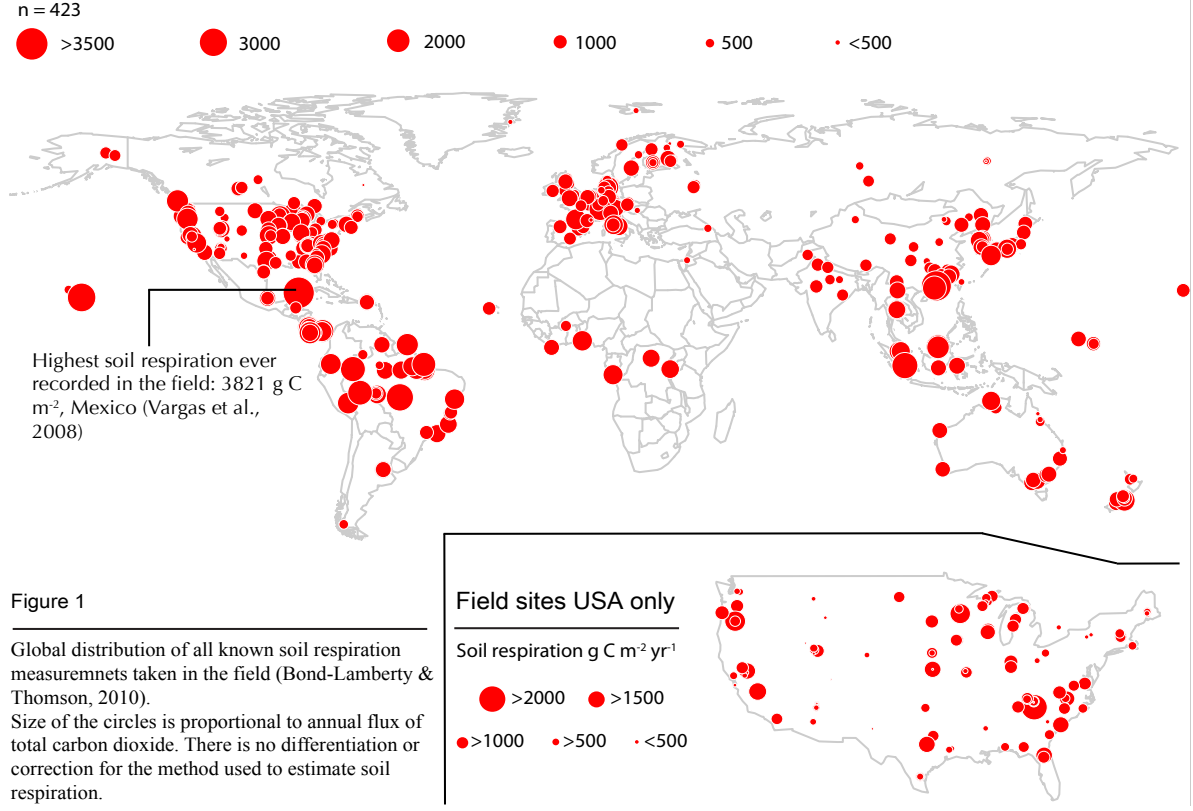

BGD

11, 1977-1999, 2014

Climate and soil respiration

C. T. Berridge et al.

Title Page

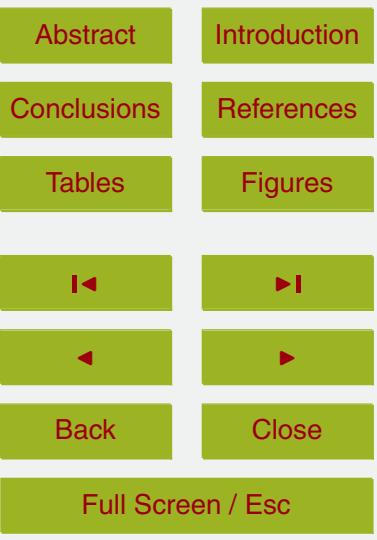

Printer-friendly Version

Interactive Discussion 

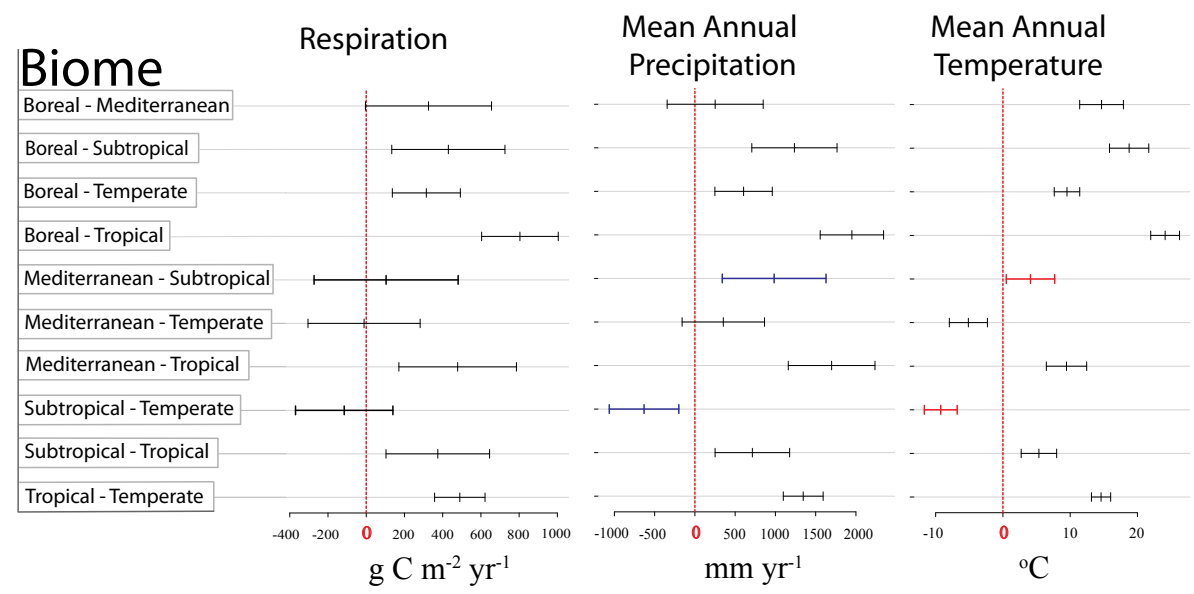

Fig. 2. Tukey's Honest Significance Difference Test (HSD) demonstrating the pairwise differences in sample means for respiration and mean annual precipitation and temperature for terrestrial biomes. Whenever the horizontal bar does not cross zero, there is a significant difference in mean value; the ninety five per cent confidence interval is proportional to the length of the bars.

\section{BGD}

11, 1977-1999, 2014

Climate and soil respiration

C. T. Berridge et al.

Title Page

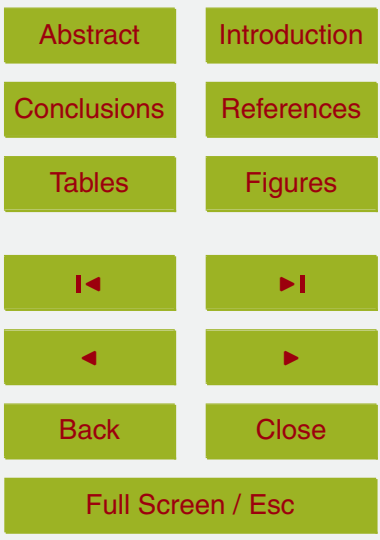

Printer-friendly Version

Interactive Discussion 
a

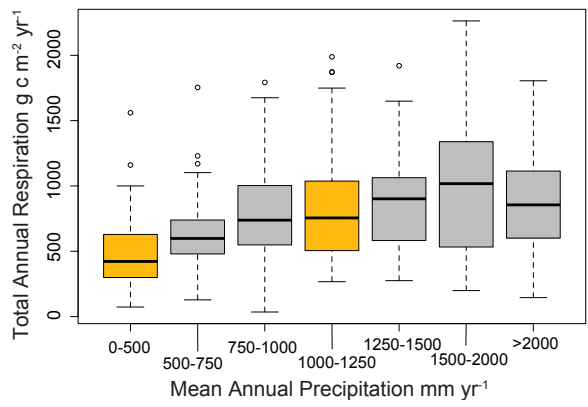

c

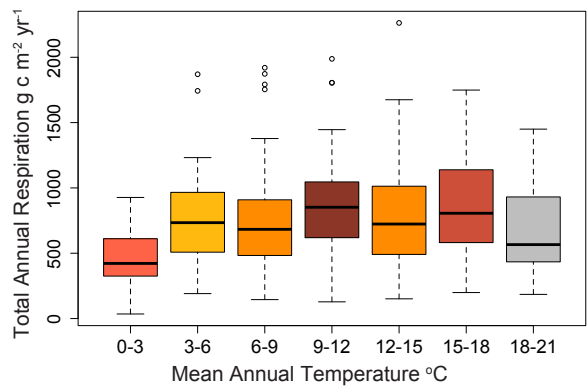

b

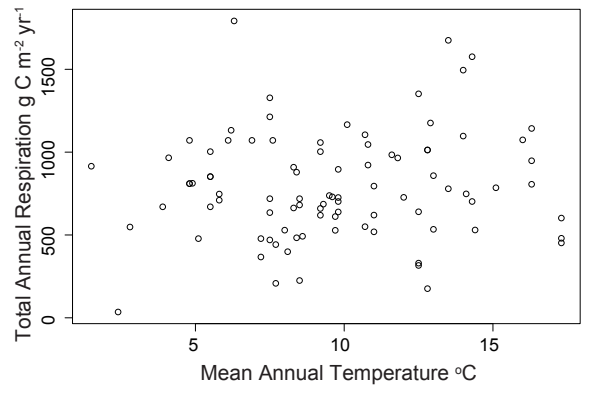

d

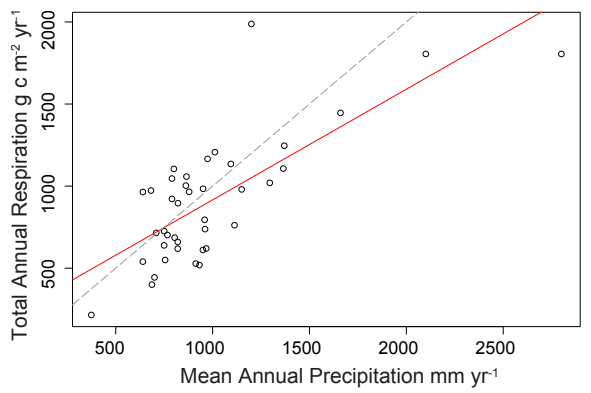

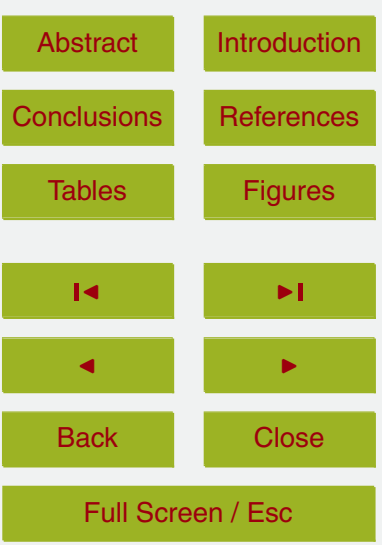

Printer-friendly Version

Interactive Discussion ted against the corresponding mean annual temperature values as the independent variable.
(c) Akin to (a), but with the same data categorized by mean annual temperature instead of by mean annual precipitation. (d) Akin to (b), this scatter plot is the respiration data taken from the $9-12^{\circ} \mathrm{C}$ range in (c) plotted against the corresponding mean annual precipitation values as the independent variable; $r=0.744, p<0.001, n=40$; grey dashed line is $1: 1$ line.

$11,1977-1999,2014$

Climate and soil respiration

C. T. Berridge et al.

Fig. 3. (a) Box-plots showing the median, range and upper and lower quartiles of the respiration data as divided by discrete precipitation ranges. Note that the median value of respiration increases linearly with each increment in precipitation, until the uppermost increment. (b) The scatter plot of the respiration data contained within the $750-1000 \mathrm{~mm}$ range in (a) plotted against the corresponding mean annual temperature values as the independent variable. 


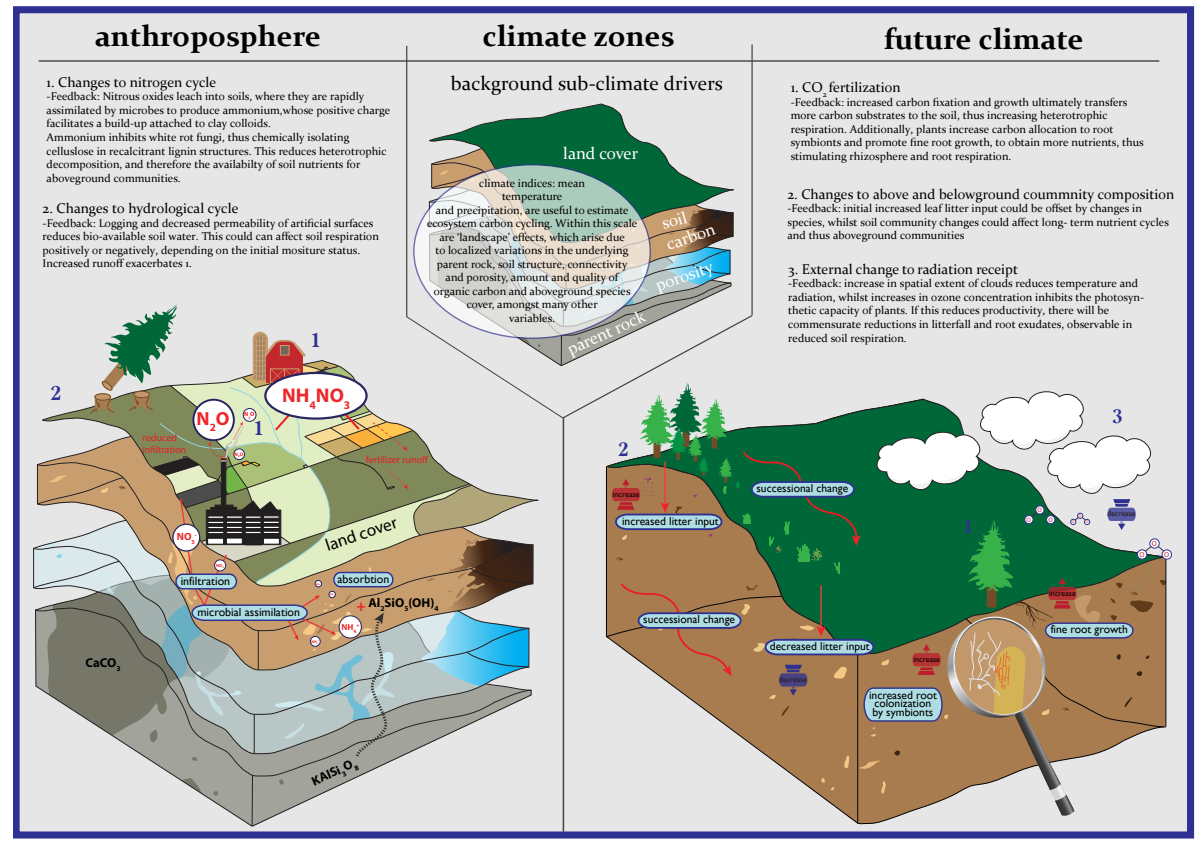

Fig. 4. Diagram illustrating important variations within climate zones (middle), the reality of human interference (left) and future potential future changes within climate zones (right).

\section{BGD}

11, 1977-1999, 2014

\section{Climate and soil respiration}

C. T. Berridge et al.

Title Page

\begin{tabular}{|c|c|}
\hline Abstract & Introduction \\
\hline Conclusions & References \\
\hline Tables & Figures \\
\hline I4 & - I \\
\hline 4 & \\
\hline Back & Close \\
\hline Full Screen / Esc
\end{tabular}

Printer-friendly Version

Interactive Discussion 


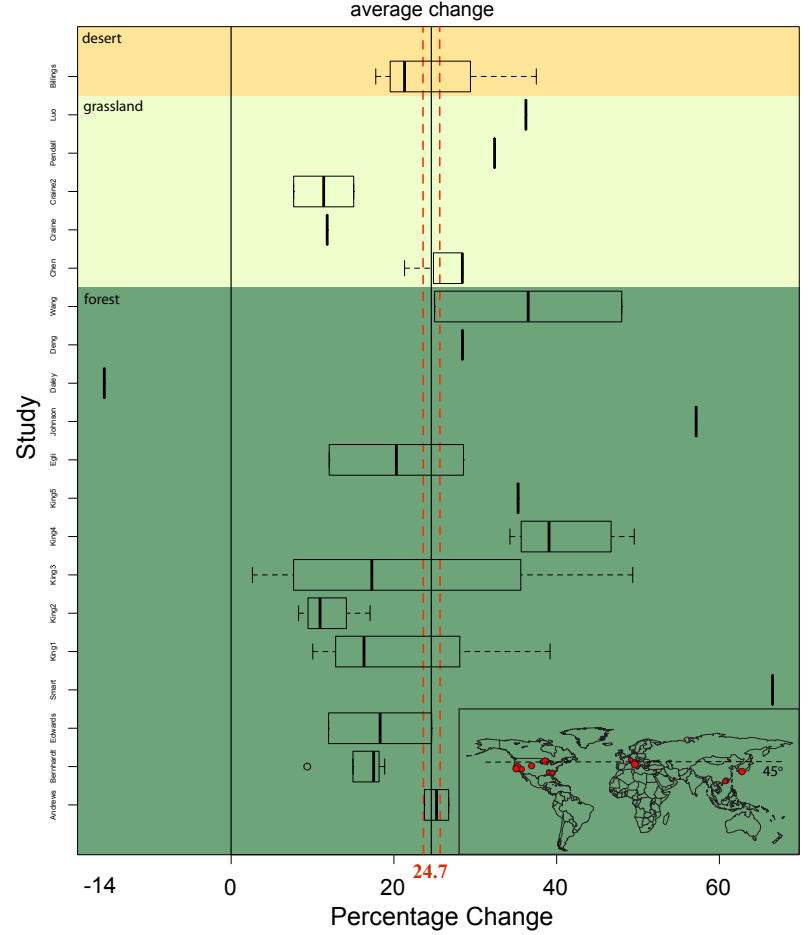

Fig. 5. Spread of effects of artificially elevated atmospheric $\mathrm{CO}_{2}$ on soil respiration for 20 independent studies, data from: King et al. (2001); King et al. (2004); Deng et al. (2010); Billings et al. (2004); Egil et al. (2001); Craine et al. (2001a, b); Edwards and Norby (1999); Bernhardt et al. (2006); Andrews and Schlesinger (2001); Daley et al. (2009); Luo et al. (1996); Pendall et al. (2003); Johnson et al. (1994); Smart and Peñuelas (2005); Chen et al. (2012); Wang et al. (2012). Average change: $24.71 \pm 1.94 \%$. Relative change (percent increase) logdecreases with higher initial soil respiration $\left(r^{2}=0.2\right.$, Supplement 4$)$.
BGD

11, 1977-1999, 2014

Climate and soil respiration

C. T. Berridge et al.

Title Page

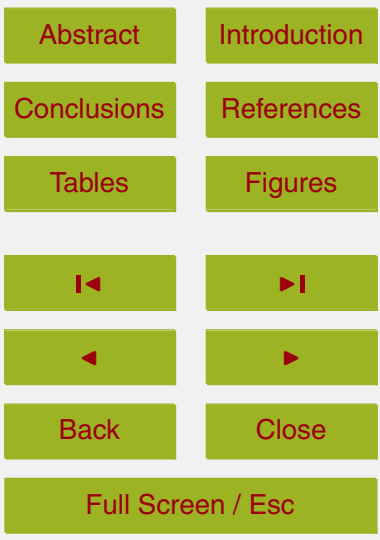

Printer-friendly Version

Interactive Discussion 